\title{
DOES ISLAMIC BANKING HAVE A FUTURE IN GERMANY? SURVEY ON GERMAN MUSLIMS PERCEPTIONS
}

\author{
DOI: 10.17261/Pressacademia.2020.1213 \\ JEFA- V.7-ISS.2-2020(10)-p.187-197
}

Ciydem Catak', Sena Yılmaz Arslan²

${ }^{1}$ Turkish-German University, Faculty of Economics and Administrative Sciences, Department of Business Administration, Istanbul, Turkey. catak@tau.edu.tr, ORCID: 0000-0001-7501-5969

2 Turkish-German University, Faculty of Economics and Administrative Sciences, Department of Business Administration, Istanbul, Turkey. sena.yilmaz@tau.edu.tr, ORCID: 0000-0002-6563-4296

Date Received: April 29, 2020

Date Accepted: June 19, 2020

To cite this document

Catak, Ç., Yılmaz Arslan, S., (2020). Does Islamic banking have a future in Germany? Survey on German Muslims perceptions. Journal of Economics, Finance and Accounting (JEFA), V.7(2), p.187-197

Permanent link to this document: $\underline{h t t p: / / d o i . o r g / 10.17261 / P r e s s a c a d e m i a .2020 .1213 ~}$

Copyright: Published by PressAcademia and limited licensed re-use rights only.

\section{ABSTRACT}

Purpose- Islamic banking is a new concept in Germany. Islamic banks in Germany aspire being the hub for Islamic finance in Europe and see their potential in the growing Muslim population. This paper aims to contribute to the limited literature from the target group's perspective, to analyze their perceptions and to test whether the promised potential exists in reality.

Methodology- An online survey with questions developed according to the characteristics of awareness, relative advantage, complexity, uncertainty and promotion was conducted to Muslims living in Germany.

Findings- The results show that there is awareness but little knowledge towards Islamic banking and its' concepts due to insufficient communication. The main reason attracting to Islamic banking is religion. In this regard peer groups play an important role. Furthermore, the findings indicate future potential for Islamic banking Germany.

Conclusion- In general there is a positive perception towards Islamic banking. Islamic banks have a rich customer portfolio and have the potential to increase their market share in Germany by offering suitable products and providing easy access to these products.

Keywords: Islamic banking, Islamic finance, Interest-free banking, Germany, German Muslims.

JEL Codes: G21, G10, F30

\section{INTRODUCTION}

Islamic banking is a banking sector firstly emerged in the sixties in Egypt and has been spreading since then especially in the early seventies mainly in Muslim countries. Yet in Western countries it has also appeared in the recent years (Casper and Allali, 2017). In particular, in the wake of the financial crisis with a transition to sustainability and the fact that during the financial crisis Islamic banks performed better than traditional banks (Parashar, 2010), Islamic finance has attracted considerable attention as a substitute for conventional finance in the industry and among researchers (Farhoush and Schmidt, 2011; Hassan and Sirajo, 2017). Furthermore, with a growing rate of 8,3\% in 2018 according the Islamic Financial Services Board Industry Stability Report (2018) the sector is showing future potential.

Islamic banking primarily complies with the Sharia rules, which are the religious laws of the Islam. According these the principles and characteristics of Islamic banking are the prohibition of interest, the prohibition of speculation, the prohibition of involvement with goods and services which are in any point of their supply chain connected with anything forbidden by Islam (haram) and the optional existence of a Sharia board as a guide for the sharia-compliance (Ecke, 2012; Rahman, 2012; Samad, 2004). To apply these principles operations are based on the profit-loss sharing paradigm with the aim to promote social justice and wealth distribution (Hassan and Sirajo, 2017). The Shariah compliance of Islamic banks is ensured by advisory boards called Shariah boards. 
Islamic finance has also emerged in Western countries with the rising Muslim population and also with the aim to attract capital from Gulf countries. The hub for Islamic finance in Europe is the United Kingdom, in the UK Islamic retail products are available since the 90 's (Ainley et al., 2007). Contrary in Germany Islamic retail banking is a quite new concept since the

launch of the first major Islamic Bank was in 2015. Although Islamic Banking is new in Germany, Islamic Finance products were available since 2004 in the Investment Banking. In 2004 a Sukuk, an Islamic Bond, was issued by the federal state Sachsen-Anhalt, and several other banks started offering Islamic investment products for corporate clients (Colditz, 2009). Even though Islamic banking is new in Germany, Germany had ever since a great potential for the Islamic banking sector because of the important Muslim population mainly with Turkish origin and because of the economic relevance of the country in Europe and in the world (Farhoush and Schmidt, 2011). Faroush and Schmidt (2011) supported this assumption with the results of their survey showing high demand in Islamic banking products among Muslims in Germany even before Islamic retail products where available in Germany.

Today two Islamic banks are operating in Germany. The first one is "KT Bank" with four branches in Germany, it is the first fully-fledged Islamic Bank in the Eurozone opened as a subsidiary of the Turkish Kuveyt Türk Bank in 2015. The Kuveyt Türk Bank belongs to the Kuwait Finance House Group. The second bank is "insha", a digital banking service, introduced in 2017 through another Turkish Islamic Bank Albaraka Türk, which is part of the Bahraini Albaraka Banking Group. Both banks aspire being the hub for Islamic finance in continental Europe. Interestingly both banks entered the German market through their Turkish brands which supports the statements that they see their potential apart from the growing Muslim population mainly in the Turkish community (Wahl-Immel, 2018; Al Baraka, 2018). This could be an important success factor as Gleisner et al. (2009) showed that Turkish immigrants in Germany prefer their home nation banks. But on the other side some researchers emphasize their concerns, they argue that religious convictions do not directly translate into the usage of Islamic banking as it can be seen in certain Muslim majority countries and that Turkish immigrants probably have doubts about Islamic investment opportunities because of the Turkish Holdings scandals in the mid 90's, where Turkish immigrants lost their money due to fraud in Islam-compliant investments. Contrariwise it can be argued that these scandals are a proof for the existing demand (Colditz, 2009; Sobol, 2015).

This paper aims to contribute to the literature from the target group's perspective. Generally, the research on Islamic banking in Germany is limited and the available studies concentrate on the regulatory framework or is out of date. Our aim is to analyze the perceptions of Muslims living in Germany towards Islamic banking to find out whether the promised potential exists in reality and to test the arguments described above. We therefore carried out a survey with specific questions that were developed according to the characteristics of awareness, relative advantage, complexity, uncertainty and promotion towards Islamic banking and its products. The broadness of the survey gave us the opportunity to measure not only general knowledge but also the perception of German Muslims towards Islamic banking in addition to the existing literature.

The paper is structured as follows. Section two gives an overview of the previous studies on Islamic banking in Germany, section three explains the data and methodology used in this study, section four presents the results of the study, finally in the last section conclusion is provided.

\section{LITERATURE REVIEW}

Since 1960 the German immigrant population has grown steadily due to high labor migration. According to the PEW report (2017), the proportion of Muslims in Germany has increased in the recent years with most of the new immigrants being Muslim. The refugee crisis, which peaked in 2015, plays an important role in this context. It is estimated that Muslims in Germany will make up one-fifth of the total population in 2050 if immigration movements continue with the same intensity. It should also be mentioned that Islam is still one of the fastest growing religions in the world as the birth rates of the Islamic population are well above the average of the entire population. Due to the trend of rising proportion of Muslims in the total population the potential demand for "Islamic" products in Germany will accordingly increase in the coming generations (Schuster, 2013).

The high number of living Muslims in Germany made many studies on Muslims necessary, and Islamic banking became one of the areas of study. Delays due to uncertainties about the concept of Islamic banking resulting from German legal rules that do not allow the inclusion of Islamic law as a legal system (Junius, 2007) have also influenced empirical studies in the field of Islamic banking. In this respect, the literature is still quite new. Especially with the opening of the Turkish KT Bank in 2015 in Germany, the literature on Islamic finance has been expanded and numerous studies have been conducted to examine Islamic financial products and the Islamic banking system. This section summarizes these studies. 
Farhoush and Schmidt (2011) tried to find out whether there is a demand for Islamic financial products on the German market, which products are mostly demanded and who the target group for these products is. To this end, they conducted an online survey of 373 respondents and found that the Muslim community living in Germany is an attractive target group for Islamic financial institutions. One important finding is that Muslims in Germany compliance with the Sharia law is more relevant, especially for people with a higher degree of religiousness. Another finding is that different cultures and beliefs should be taken into account and correspondingly different Islamic products should be offered to the Muslim communities living in Germany matching their needs. A further important topic is the improvement of general financial education. According to the survey results, interest in normal financial products and Islamic financial products increases with increasing financial knowledge. Finally, as in many other studies, the importance of developing marketing activities is emphasized.

In another study, Usai (2016) examined whether Islamic banks could be an alternative to conventional banks. The study defines Islamic banking as ethical banking and underlines the advantages such as strengthening the economy and preventing the emergence of a new banking crisis. As in many studies, it is stated that Islamic banks should be sufficiently marketed to rise the knowledge as with more knowledge the preference towards the products rises. The study points out that Islamic banking offers more market potential due to the refugee crisis than under normal conditions. So, information on Islamic financial products should be improved and a training course on the basics of Islamic banking should be offered. On the other hand, it is argued that many people did not want Islam to be part of German culture, which would make the development of Islamic banking in Germany more difficult. In a similar study, Alharbi (2016) states that the education system in the Western countries could raise awareness of the Islamic financial industry. He argues that the Islamic financial industry must address the problems of Islamophobia and solve the legitimacy issue of Islamic contracts. He concluded that the German government does not officially support Islamic banking and stated that the Islamic financial sector in Germany is currently developing and has a long way to go. One of the studies that said that further marketing efforts should be carried out for the development of Islamic banking in Germany was conducted by Beloucif, Boukhobza and BaumruckLawrenz (2017). They investigate perceptions, opinions and concerns regarding Islamic banking in Germany. From personal interviews with Muslim and non-Muslim clients in Germany, they conclude that different marketing strategies need to be designed and implemented in the German market.

Casper and Allali (2017) focused on KT Bank in their study, discussed the current status of this bank and examined some of its products. Furthermore, they analyzed the corporate governance structure of KT Bank and approached it in the context of corporate social responsibility through interviews and questionnaires. They listed the main difficulties regarding the opening process of the bank, the existence of the Sharia Supervisory Board and its privileges over the Board of Directors, as well as the double taxation problem resulting from the use of Islamic financial instruments based on profit sharing.

Expectations regarding the further development of Islamic banking and finance in Germany are relatively high. Di Mauro, Caristi, Couderc, Maria, Ho, Grewal, Masciantonio, Ongena and Zaher (2013) underline three reasons for this. Firstly, Germany is one of the largest economies in Europe and has one of the largest Muslim populations. Secondly, German exporters can use Islamic finance instrument as alternative finance sources and thus further improve their financing profile. Thirdly, Islamic trade finance products help Germany to strengthen its trade relations with its active trading partners such as Turkey, which has an emerging Islamic financial sector.

Schuster (2013) emphasizes that the offer of Islamic banking in Germany creates an advantage for all participants. For Muslims in Germany, this offers the opportunity to use financial services that are appropriate to their religion. German banks also have the opportunity to gain new market shares, especially in retail banking, and to strengthen business relationships with Muslim customers through Sharia-compliant products. Furthermore, by concentrating on investment activity and lending, the needs of society and the real economy can be met better. Finally, the liability and financial burden on governments will be reduced with increasing stability in the financial markets.

\section{DATA AND METHODOLOGY}

An online survey was used to measure the knowledge and attitudes of Muslims living in Germany towards Islamic banking. The questions were prepared in German language. A pilot test with eleven participants was initially conducted to check the clarity of the questions.

The survey consists of six groups of questions on the attributes of awareness, relative advantages, complexity, uncertainty, perception and promotion. The questions in the first group were designed to measure the participants' knowledge of Islamic banking products and services. The questions in the second group include questions comparing Islamic banking with conventional banking. Here we aim to find out the reasons for choosing Islamic banking and the advantages towards 
conventional banking. In the third group it is examined whether concept of banking, its services and product are complex and whether the participants have difficulties in understanding the processes. In the fourth part the uncertainty in connection with Islamic banking is measured, in other words we examined, whether there are any doubts about Islamic banking. In the fifth part we tried to understand the perception towards Islamic Banking in Germany. Here the questions measure the opinions about current situation and future perspective and the disadvantages of Islamic banking in Germany. In the sixth part we concentrate on Islamic banks' promotional activities and tried to understand the impact of the promotional efforts and their influence. In total the survey consisted of 40 questions. While the questionnaire includes single-choice questions and multiple-choice questions, the main question type is the Likert scale question. The Likert scale used is ranged like following; definitely agree, agree, undecided, disagree and strongly disagree.

Table 1: Summary of Gender and Age Statistics of Participants

\begin{tabular}{|c|c|c|c|c|}
\hline \multicolumn{2}{|c|}{ Female } & \multicolumn{2}{c|}{ Male } \\
\hline Frequency & Share & \multicolumn{2}{c|}{ Frequency } & \multicolumn{2}{c|}{ Share } \\
\hline 41 & $57 \%$ & 31 & $56 \%-55$ \\
\hline \multicolumn{5}{|c|}{ Age } \\
\hline $18-25$ & $26-35$ & $36-45$ & $17 \%$ & $1 \%$ \\
\hline $40 \%$ & $29 \%$ & $13 \%$ & \\
\hline
\end{tabular}

A total of 72 Muslims living in Germany took part in the survey. The survey was distributed among German Muslims randomly in 2019. The age of the respondents varies between 18 and 65 years. $40 \%$ of the participants are between 18 and 25 years old and make up the largest share. On the other hand, 29\% of the participants are between 26 and 35 years old and only $1 \%$ are over 55 years of age. If we categorize according to gender, the proportion of women among the participants, at around 57\%, is higher than the share of male participants. Originally the survey was shared with approximately 200 Muslims living in German. In total, 120 results are gathered, of which only 72 were assessable. Nevertheless, the sample size gave us meaningful results in the qualitative analysis which are consistent and complementary in regard to the literature.

\section{FINDINGS AND DISCUSSIONS}

In the following, the consumer perception of Islamic banking and its products is analyzed within in the scope of the results of our survey, which is used as the methodological measurement tool.

The first group of questions aims to find out the respondents' knowledge of Islamic banking products and services. 39 people among the participants, which made up 54 percent, stated that they had information about Islamic banking, the other 33 participants are not familiar with the Islamic banking construct. Although more than half of the participants had already heard of Islamic banking, $61 \%$ of the participants are not aware of the existence of Islamic banks in Germany. Furthermore, only 6 of the respondents are customers of Islamic banks in Germany, 5 of them are customers of KT Bank and one participant is a customer of Inaia $\mathrm{GmbH}$, a non-bank Islamic finance institution. 
Figure 1: Knowledge of Islamic Banking

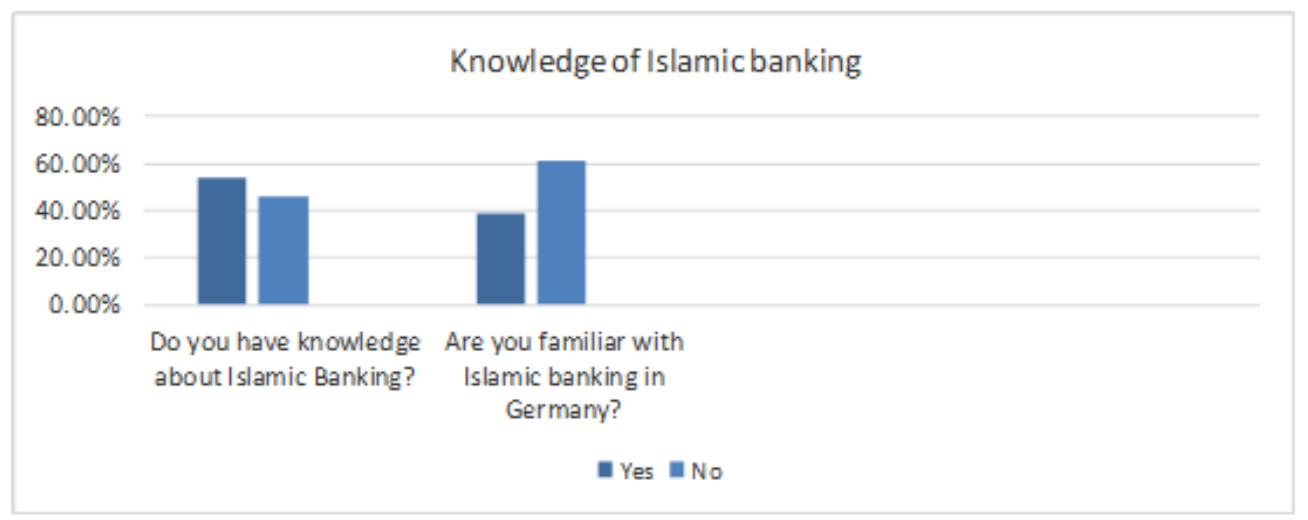

Considering the answers to the question regarding the specific knowledge of the products and services of Islamic banking, it can be concluded that Muslims living in Germany are not familiar with most Islamic banking services and products. Almost half of the participants (45\%) know that they can open a bank account at an Islamic bank, but still $54 \%$ of the participants even do not know that they can open a bank account at an Islamic bank. Further, they do not know that these banks offer different opportunities such as investment products, financial products, money market instruments and insurance products like traditional banks. For example, almost all participants (96\%) do not know that trade finance instruments are available in Islamic banks. The same applies to money market instruments and insurance products. Only $6 \%$ of the respondents know that money market instruments are among the interest-free banking products and only $8 \%$ know Islamic insurance products. The lack of marketing strategies for the introduction of Islamic banking becomes clear with these results.

Another question evaluates the participants' knowledge of the characteristics of Islamic banking. It can be seen that most participants do not believe that Islamic banking services and products are intended only for Muslims, but that these banks serve both Muslims and non-Muslims. The proportion of respondents who say that they are aware that Islamic banking products are based on the principles of Sharia law is about 55\%. Just $19 \%$ does not know that Islamic banks operate according the Sharia law. A big majority with $77 \%$ of the respondents knows that interest is prohibited in Islamic banking. Again, a majority of $58 \%$ knows that Islamic banking is based on the profit-loss sharing principle. Looking at prohibition of uncertainty and involvement in business which are prohibited by the Sharia (haram) the knowledge of the participants is $52 \%$ and $65 \%$. 
Figure 2: Knowledge of the Products and Services of Islamic Banking

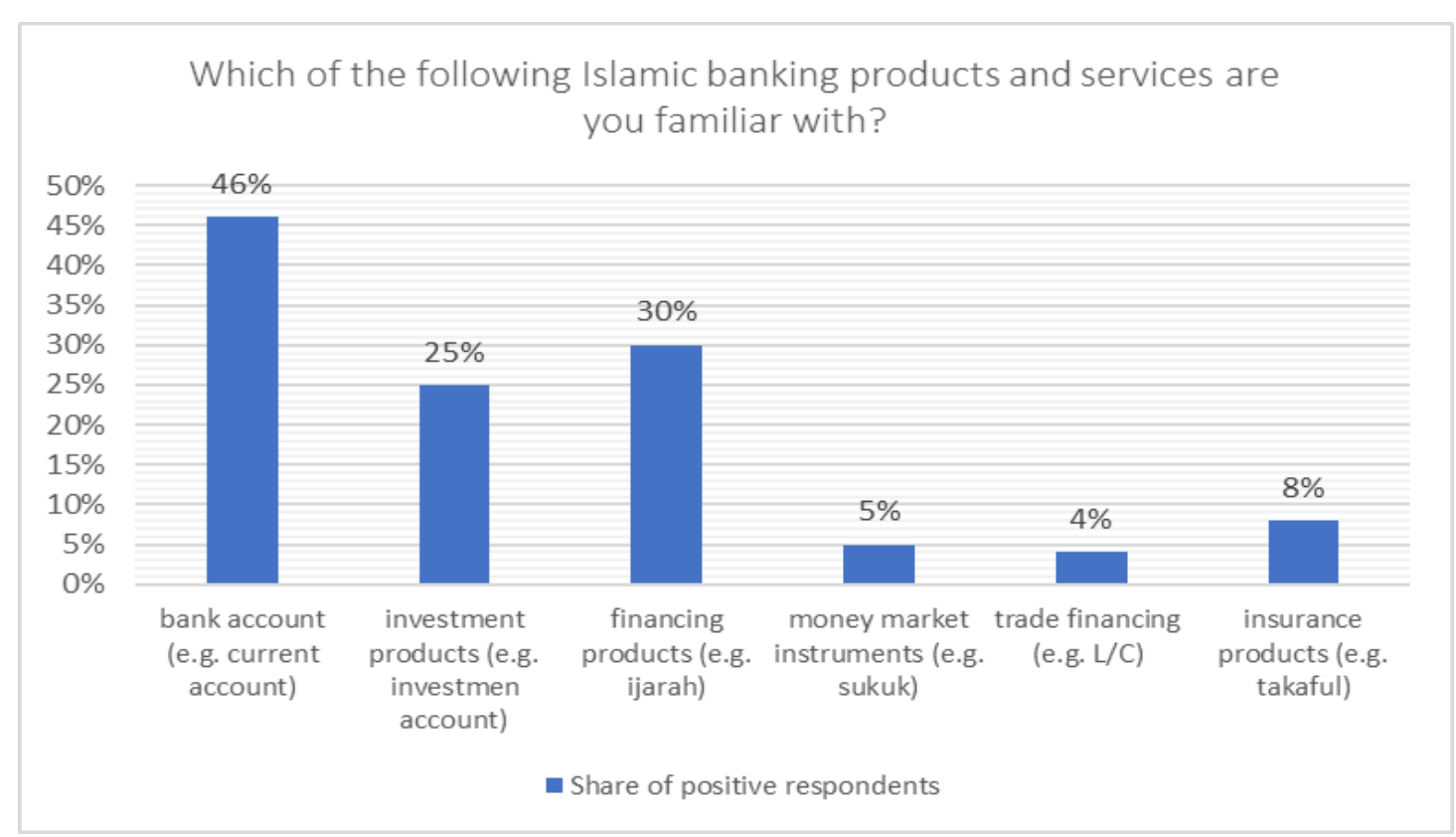

The answers of part one show that there is a relative majority in awareness towards Islamic banking and the existence in Germany. But specially the use of Islamic banking, and product knowledge is very low. Nevertheless, there is still a majority in awareness towards the principles and concept of Islamic banking. The result can be interpreted as lack of promotion, which can also be seen in the following parts.

The second part of the questionnaire contains questions on the relative advantages of Islamic banking. Firstly, the participants where asked which factors would encourage them to use Islamic banking services, they could choice multiple answers. About 85 percent of the respondents have chosen religion. Another outstanding reason for the participants to prefer Islamic banking is reliability. Approximately 68 percent of respondents said they considered Islamic banking services and products reliable. In the second question of this part the participants answered assessed statements the advantages of Islamic Banking. The service in the native language, which is claimed in others studies as an important reason for choosing Islamic banks, was not seen by our respondents as a reason for preferring Islamic banking. With an important majority 57 percent of the respondents said that the service offered in other languages like Turkish and Arabic was not important to them. Only 26 percent considered language as an important factor in their choice. The majority with $57 \%$ of the respondents agrees with the statement that Islamic loans will reduce the burden of predetermined interest rates imposed by the traditional banking system. Interestingly seeing interest rates as a burden, the participants are relatively undecided regarding the main Islamic PLS principle. The percentage of people who say that returns based on the principles of profit sharing are definitely more financially attractive to them is about $38 \%$. But the number of people who are undecided about the same question is also $38 \%$. This high uncertainty shows the confusion about the Islamic banking principles but also the negative attitude towards interest rates. In line with the first part a high percentage of the respondents (71\%) agree with the statement that Islamic banking products are in line with their belief. 
Figure 3: Relative Advantages of Islamic Banks

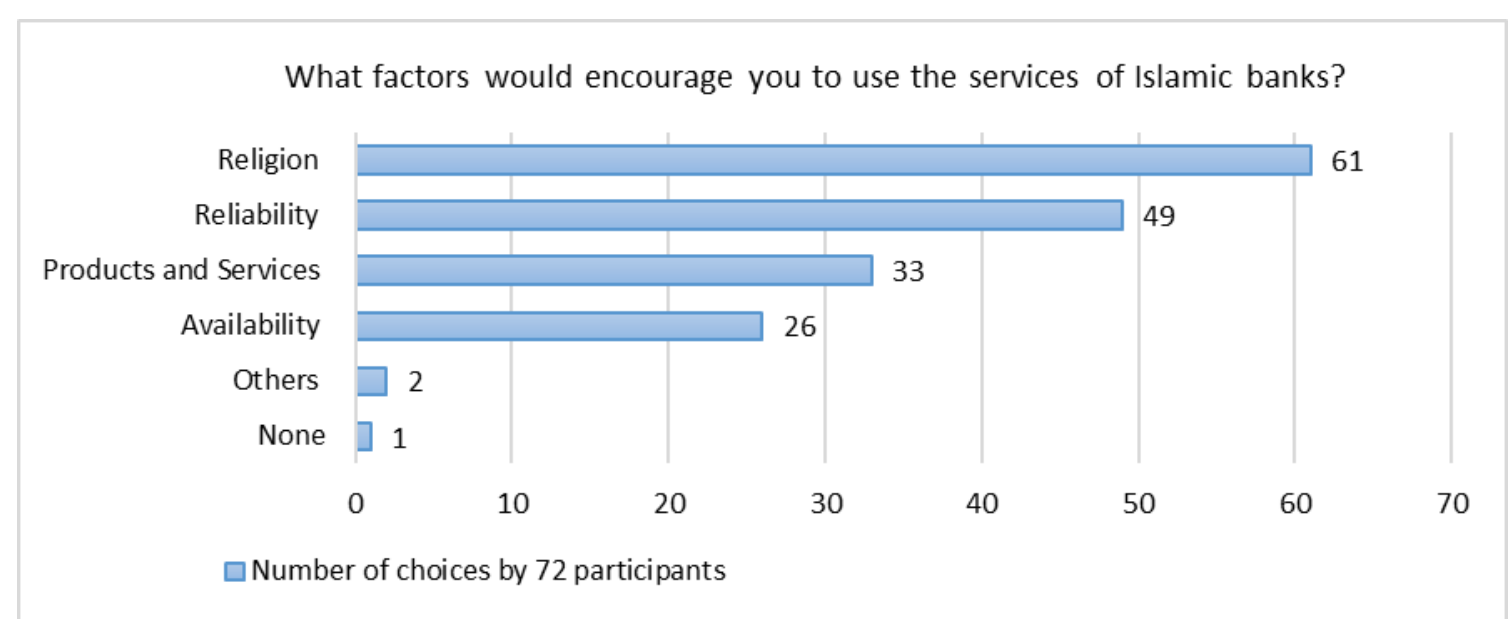

Among the participants of the questionnaire there are different opinions about the performance of Islamic banks in times of financial crisis, despite the studies in the literature showing that Islamic banks performed better during the last financial crisis in 2008. About 43 percent of the participants were not sure whether Islamic banking had fewer difficulties than traditional banks during the financial crisis. However, 38 percent of the participants believe that Islamic banks can perform better in times of financial crisis and support the literature with this thought.

In total, we can see in this part that religion is the biggest motivation for the use of Islamic banking. We can also see that there is some discontent about conventional banking. But the lack of knowledge of Islamic banking products and principles hinders a deeper assessment of the relative advantages.

In the third part of the survey we try to measure whether the concept, services and products of Islamic banking are difficult to understand and to show whether the concepts of Islamic banking are too complicated. The respondents rate six statements about complexity with the Likert-Scale. In general, the answers show the lack of knowledge about Islamic Banking and in line with that the respondents are in the majority of the cases undecided about the statements. So, the respondents are largely undecided about the complexity of Islamic banking products, procedures and principles. But they also do not think that the Islamic banking products are complex. In detail, the corporate governance structure of Islamic banks is unknown to majority of the respondents. About 72 percent of the respondents said that they either had no knowledge of the corporate governance structure of Islamic banking or very little. Further, they are not sure whether it is difficult to open an account at an Islamic bank, despite having an idea about whether the application procedure for loans at Islamic banks is difficult. The question about the repayment process of an Islamic loan shows us also that the respondents have no idea about this process. Only 7 participants believe that Islamic loans involve a complicated repayment process, 28 respondents believe that Islamic loans do not involve a complicated repayment process and 37 respondents are undecided.

Table 2: Summary Complexity

\begin{tabular}{|l|c|c|c|c|c|}
\hline $\begin{array}{l}\text { Statements on Islamic banks' level of } \\
\text { complexity }\end{array}$ & Disagree & $\begin{array}{c}\text { Slightly } \\
\text { disagree }\end{array}$ & $\begin{array}{c}\text { Neither } \\
\text { agree nor } \\
\text { disagree }\end{array}$ & $\begin{array}{c}\text { Slightly } \\
\text { Agree }\end{array}$ & Agree \\
\hline $\begin{array}{l}\text { The procedure for opening an account at } \\
\text { an Islamic bank is difficult. }\end{array}$ & 20 & 16 & 29 & 4 & 3 \\
\hline $\begin{array}{l}\text { The application for a loan from an Islamic } \\
\text { bank is a complex process. }\end{array}$ & 15 & 16 & 36 & 10 & 1 \\
\hline $\begin{array}{l}\text { The repayment process for Islamic loans is } \\
\text { complicated. }\end{array}$ & 16 & 12 & 37 & 6 & 1 \\
\hline $\begin{array}{l}\text { Islamic bank terms are difficult to } \\
\text { understand. }\end{array}$ & 11 & 16 & 27 & 14 & 4 \\
\hline
\end{tabular}




\begin{tabular}{|l|l|l|l|l|l|}
\hline $\begin{array}{l}\text { The concept of profit and loss sharing is } \\
\text { difficult to understand. }\end{array}$ & 16 & 14 & 28 & 13 & 1 \\
\hline $\begin{array}{l}\text { The corporate governance structure of } \\
\text { Islamic banks is not clear to me. }\end{array}$ & 14 & 6 & 18 & 17 & 17 \\
\hline
\end{tabular}

The questions in the fourth section are about uncertainty. We asked whether the difference between Islamic banks and traditional banks is understandable. While 50 percent of respondents said that the difference between Islamic and traditional banks is clear, the rate of those who do not understand the difference between Islamic banks and traditional banks is still almost 24 percent. On the other hand, when assessing the answers of the participants whether Islamic banks adhere to Islamic principles, there the majority has no doubt about the fact that Islamic banks are governed by Islamic principles. About 47 percent of the respondents believe that Islamic banks adhere to Islamic principles, just a minority of 18 percent of the respondents suspicious of Islamic banking whereas a majority with $47 \%$ has no doubt about Islamic banking despite being a new and unique structure. For Islamic banks, the percentage of respondents who see the lack of a legal basis and regulations in Germany as a disadvantage is around $28 \%$. The percentage of those who do not see this situation as a disadvantage is around 35\%. Despite the fact that the questions in this part where in form of negative clauses for the disadvantage of Islamic banking the majority of the respondents has no doubts about Islamic Banking and its concepts. There seems to be trust in Islamic banking.

In the fifth part of the survey we try to measure the perception of the participants towards Islamic Banking in Germany. A majority of $46 \%$ of respondents think that there is great potential for Islamic banking products in Germany. On the other hand, $25 \%$ of the participants do not see a future for Islamic banking in Germany. The number of people who believe that Islamic banks in Germany can compete with traditional banks is almost equal to the number of people who do not believe this and to the respondents which are undecided. In next question whether Islamic banking products in Germany are similar to those of traditional banks with the difference Islamic banks label the products differently there is also no significant answer. This shows again the lack of knowledge of product. In the literature this topic is a widely discussed topic, many researchers believe that Islamic banking products are just named differently than conventional products but are of the same nature in their core (Asutay, 2012; El-Gamal, 2007).

The respondents are also confused about the advantages of Islamic banking in Germany towards conventional banking. Most of the participants (43\%) could not decide whether Islamic banking in Germany is more advantageous than conventional banking. While $33 \%$ of the participants think that Islamic banking in Germany is more advantageous, the rate of those who think the opposite is $23 \%$. The majority with $48 \%$ of the participants believe that misunderstandings and misconceptions towards Islam have a negative impact on Islamic banking in Germany. Only $17 \%$ of those surveyed believe that misunderstandings about Islam have no negative impact on Islamic banking. This aspect shows also the problem which can arise with the religious aspect of the banking especially in Western countries. This is in line with the Islamophobia discussion and the belief that many people do not want Islam to be part of German culture. Concluding, on the one hand the participants believe that there is potential for Islamic banking in Germany, on the other hand the participants are aware of the possible social problems. 
Figure 4: Perceptions Islamic Banking in Germany

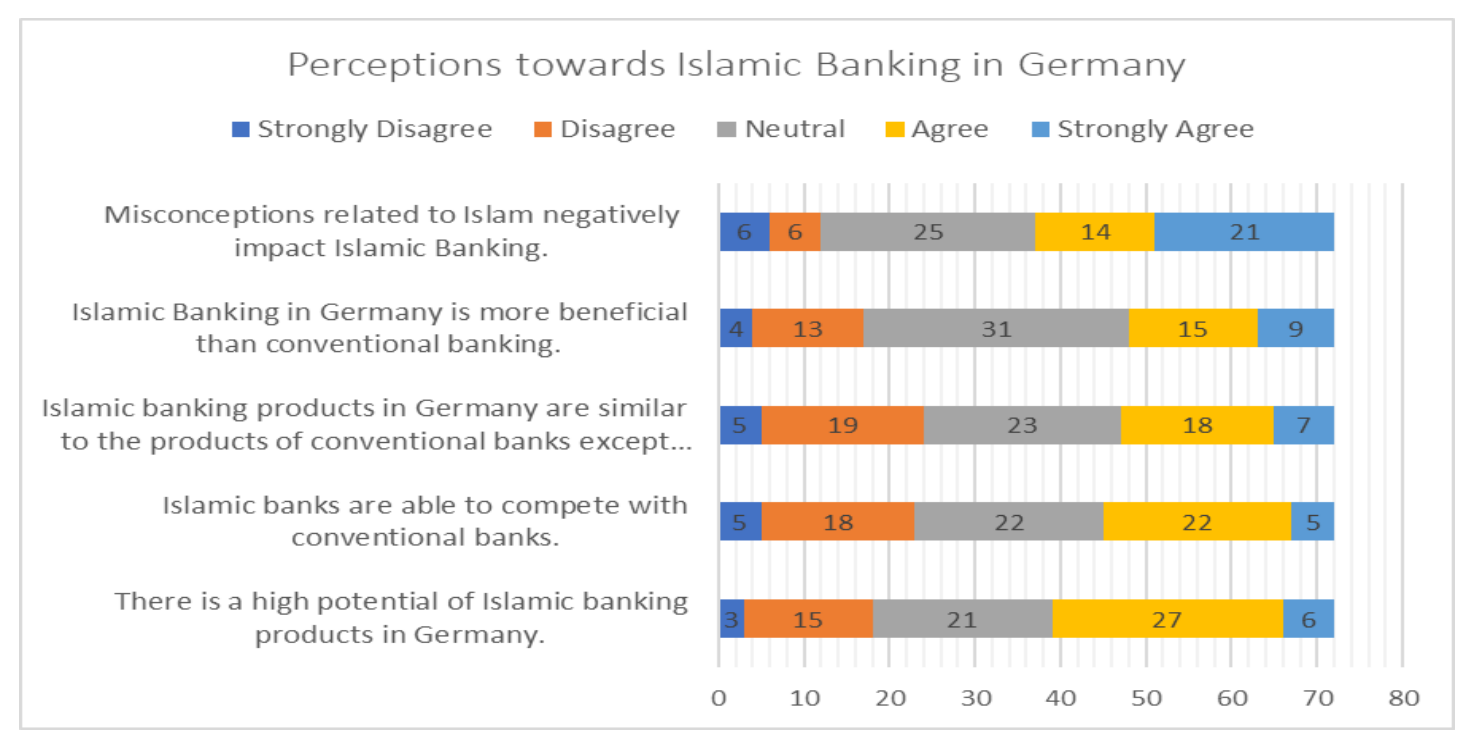

The sixth part of the survey consists of questions regarding the communication channels of Islamic banking and the quality of the information received. We asked participants where they often obtain information about Islamic banking. They could tick more than one answer and state their own option. Half of the respondents indicated that they receive information about Islamic banking from their family, friends and colleagues. While $44 \%$ of respondents said that they received information about Islamic banking from the Internet, 39\% said that they received information during their mosque visits. But about $24 \%$ of the respondents indicated that they had received information about Islamic banking from television advertisements, while only $10 \%$ indicated that they had found information about Islamic banking in newspapers. Interestingly, the rate of those who say I get information in social media is very low. The answers show that peer groups play an important role and that the professional advertisements in the wider media are either very low or do not reach the target group.

\section{Figure 5: Communication channels}

Where do you often come across with advertising related to Islamic banking?

Family/friends/colleagues

Mosque visit

Website of the bank

None
Radio advertisement

Pamphlets

Own research

Telemarketing

(a)

0

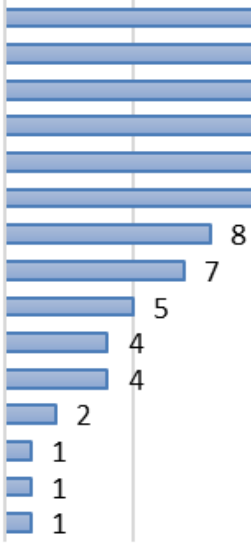

5

10

15

$\square$ Number of choices by 72 participants

20

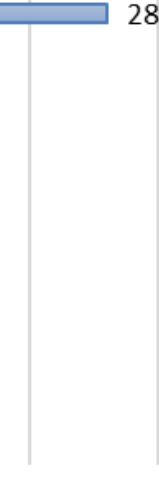

30

35

40 
If we look at the questions about the quality of the information received, the share of respondents who say that they do not receive understandable information about Islamic banking is $47 \%$. Just $25 \%$ of the respondents believe that they do not receive clear information. $26 \%$ of the participants believe that the access to information about Islamic banking is easy. The rate of people who think the opposite is $43 \%$. Another important issue regarding communication channels is the rate of those who say that Islamic banks have sufficiently marketed their products to the public. Only 8 percent think that the marketing activities are sufficient. A big portion with $72 \%$ of the participants think that Islamic banks do not adequately market their products to the public. In total a lack of communication can be observed.

In total, it can be seen that there is somehow an awareness towards Islamic banking and its' concepts, nevertheless this awareness is very superficial. It seems like the Islamic banks' promotion activities are not sufficient enough. Still it can be argued that there is future potential for Islamic banking Germany due to the results showing religious demand and high trust in Islamic banking. The results of the survey summed up in Table 3.

Table 3: Summary of the Survey Results

\begin{tabular}{|l|l|}
\hline Awareness of Islamic Banking Products and Services & - Majority is aware of Islamic Banking and its' principles. \\
\hline Relative Advantage & - Knowledge of products and the usage is very limited. \\
\hline Complexity & $\begin{array}{l}\text { - Main reason attracting to Islamic Banking is religion and } \\
\text { reliability. }\end{array}$ \\
\hline Uncertainty & - Dissatisfactions with interest in conventional banking. \\
\hline Perceptions towards Islamic Banking in Germany & - Lack of knowledge leads to no significant results in this part. \\
\hline Promotion & - Majority has trust in Islamic banks. \\
\hline & $\begin{array}{l}\text { - Majority thinks that the Islamic banking has a potential in } \\
\text { - Majority is aware of possible social problems in Germany. }\end{array}$ \\
\hline
\end{tabular}

\section{CONCLUSION}

The recent financial and banking crises have forced the world to review existing banking systems. Islamic banking, a new banking model combines religion and finance and therefore plays an important role at this point. These banks give positive signals to the economy because of their ethical banking concept and their positive prospect in regard of the emerging Muslim economies and the growing Muslim population worldwide. The success of these banks has already been proven in Great Britain, the MENA region and South East Asia and the sector is becoming increasingly important across the globe.

Although the Islamic banking system in Germany emerged late compared to other European countries, Muslims in Germany take the possibility of financial transactions under Islamic law seriously. KT Bank, the first Islamic bank in Germany, is a successful example in this regard. It works on the basis of the Sharia principles of Islam and while it also acts in compliance with the German codes and regulations.

In the above discussion we gave an overview of the evolution of Islamic banking in Germany. In addition, we analyzed the concept of Islamic banking and measured the perception of Muslims as our aim was to contribute to the literature with an up-to-date perspective of the main target group. In respect of our introducing question whether the promised potential of Islamic banking really exists we can say that our analysis underlines the claims of the Islamic banks in Germany and mostly the arguments of the previous literature. We can see that the growing Muslim population is a future potential as religion is proven as the main reason of choosing Islamic banking in our survey. This is in line with the results of Faroush and Schmidt (2012). Faroush and Schmidt (2012) further argue that financial knowledge is low among German Muslims, which is also seen in our results. This could be partly due to the insufficient communication shown in our results in compliance with Beloucif et. al. (2017). On the other side our analysis shows a general positive perception towards Islamic banking contradictory to the arguments of Colditz (2009) and Sobol (2015) which claim that there could be trust problems towards Islamic banking in Germany.

In conclusion Islamic banks that offer goods and services which comply with Sharia laws and have a rich customer portfolio from different nations and cultures have the potential to increase their market share in Germany by offering suitable 
products and providing easy access to these products. Concerning this matter, it is also important to introduce Islamic banking products and services more effectively to the Muslim community in Germany through suitable marketing activities.

\section{REFERENCES}

Ainley, M., Mashayekhi, A., Hicks, R., Rahman, A., \& Ravalia, A. (2007). Islamic Finance in the UK: Regulation and Challenges. Financial Services Authority

Al Baraka (2018). Press Release- Al Baraka Launches Europe's First Interest Free, Digital only Banking Service "insha" in Germany. Retrieved May 21, 2020, from https://www.albaraka.com.tr/pdf/Albaraka-insha-berlin-event-PR-Final-01102018.pdf (21.05.2020)

Alharbi, A. (2016). Development of Islamic Finance in Europe and North America: Opportunities and Challenges. International Journal of Islamic Economics and Finance Studies, 2 (3), 109-136. doi:10.12816/0036633

Asutay, M. (2012). Conceptualising and Locating the Social Failure of Islamic Finance: Aspirations of Islamic Moral Economy vs the Realities of Islamic Finance. Asian and African Area Studies, 11 (2), 93-113. available at SSRN: https://ssrn.com/abstract=2089793

Beloucif, A., Boukhobza, T., \& Baumruck-Lawrenz, L. (2017). A study of German consumers' perception of Islamic banking. Int. J. Islamic Marketing and Branding, 2 (1), 37-64. doi: 10.1504/IJIMB.2017.10004189

Casper, M., \& Allali, A. (2017). Islamic Finance Made in Germany - A Case Study on Kuveyt Türk (KT Bank): Germany's First Islamic Bank. Available at SSRN: https://ssrn.com/abstract=3077366 or http://dx.doi.org/10.2139/ssrn.3077366

Colditz, K. (2009). Islamic banking - a worthwhile challenge for German banks?. Master thesis, Technische Hochschule Nürnberg, Nürnberg Ecke, D. (2012). Islamic Banking: Grundlagen und Potenzial in Deutschland. Hamburg

El-Gamal, M. (2007). Islamic Finance: Law, Economics and Practice. Cambridge, Cambridge University Press

Di Mauro, F., Caristi, P., \& Couderc, S. et al. (2013). Islamic Finance in Europe. ECB Occasional Paper No. 146, available at SSRN: https://ssrn.com/abstract=2251204

Gleisner, F., Hackethal, A., \& Rauch, C. (2009). Migration and the retail banking industry: An examination of immigrants' bank nationality choice in Germany. European Journal of Finance 16(5), 459-480. doi: 10.1080/13518470903314410

Hassan, M. Kabir, \& Sirajo, A. (2017). An Empirical Literature Survey of Islamic Banking. Available at SSRN: https://ssrn.com/abstract=2980516 or http://dx.doi.org/10.2139/ssrn.2980516

Farhoush, A., \& Schmidt, N. (2012). Chapter 12: Islamic Finance in Germany: Trends, Opportunities, and Potential. In K. Hassan; M. Mahlknecht (Editors), Islamic capital markets: Products and strategies (pp. 235-266). Chichester, West Sussex, U.K: Wiley. doi: https://doi.org/10.1002/9781119206040.ch12

Islamic Financial Services Board (2018). Islamic Financial Services Industry Stability Report

Junius, A. (2007). Islamic Finance: Issues Surrounding Islamic Law as a Choice of Law under German Conflict of Laws Principles. Chicago Journal of International Law 7(2), 537-550. Available at: https://chicagounbound.uchicago.edu/cjil/vol7/iss2/10

Parashar, S. P. (2010). How Did Islamic Banks Do During Global Financial Crisis? Banks and Bank Systems, 5(4), 54-62.

Pew Research Center (2017). available at: https://www.pewforum.org/2017/11/29/europes-growing-muslim-population/

Rahman, N. U. (2012). Attitude of Muslims towards Islamic Banking and Finance in the NorthWest of England: A Socio-Economic Perspective, Durham theses, Durham University. E-Theses Online: http://etheses.dur.ac.uk/6394/

Samad, A. (2004). Performance of interest-free Islamic banks vis-à-vis interest-based conventional banks of Bahrain. IIUM Journal of Economics and Management 12(2), 1-15.

Schuster, F. (2013). Perspektiven des Islamic Banking im deutschen Bankwesen. Deutsches Institut für Bankwirtschaft - Schriftenreihe, Band 10 (b)

Sobol, I. (2015). Islamic Banking in the European Union Countries. European Integration Studies 9. doi: http://dx.doi.org/10.5755/j01.eis.0.9.12806

Wahl-Immel, Y. (2018, January 19). Finanzgeschäfte nach Allah - Islamisches Banking wächst. Retrieved May 20, 2020, from https://www.fnp.de/wirtschaft/finanzgeschaefte-nach-allah-islamisches-banking-waechst-10430531.htm

Usai, D. (2016). Islamic banking as an alternative to conventional banking. HFU Business School, International Business Term Paper 